\title{
A CRISE DA SEPARAÇÃO DOS PODERES E O “MIDIATISMO” DO JUDICIÁRIO BRASILEIRO: UMA ANÁLISE DOS RISCOS DEMOCRÁTICOS DE UM "SUPERPODER"
}

\author{
Ivo Dantas ${ }^{1}$ \\ Lívia Dias Barros²
}

\begin{abstract}
RESUMO
O presente texto tem como objetivo analisar o atual papel do Poder Judiciário na estrutura dos Poderes da República Federativa do Brasil. A pesquisa utilizou-se de uma metodologia de análise qualitativa com abordagem indutiva. Numa perspectiva crítica pretende-se conhecer o fenômeno da judicialização das relações sócio-políticas, considerado, um dos fatores ensejadores para a crescente atuação do Judiciário, em especial, protagonizado pelo Supremo Tribunal Federal, dentro do que se convencionou chamar de ativismo judicial. Neste sentindo, almeja-se indagar sobre a legitimidade e a eficácia do ativismo judicial no Brasil e a influência do poder da mídia nas decisões da Suprema Corte.
\end{abstract}

\section{Palavras-chave:}

Separação dos poderes; Midiatismo; Judicialização; Ativismo judicial;Superpoder

\section{THE CRISIS OF THE SEPARATION OF THE POWERS AND THE "MIDIATISM" OF THE BRAZILIAN JUDICIARY: AN ANALYSIS OF THE DEMOCRATIC RISKS OF A "SUPERPOWER"}

\begin{abstract}
This paper aims to analyze the current role of the Judiciary in the structure of the powers of Brazil. The research used a methodology of qualitative analysis with an inductive approach. In a critical perspective we intend to know the phenomenon of the judicialization of sociopolitical relations, considered, one of the factors conducive to the growing performance of the Judiciary, especially, carried out by STF, within what is known as judicial activism. In this sense, it is sought to inquire about the legitimacy and effectiveness of judicial activism in Brazil and the influence of media power on Supreme Court decisions
\end{abstract}

\section{Keywords:}

Separation of powers; Media; Judiciary; Judicial activism; Super power

\footnotetext{
${ }^{1}$ Livre-docente - UFPE; Doutor em Direito - UFMG; Mestre em Sociologia - UFPE; Especialista em Direito Público - UNICAP. E-mail: profivodantas@uol.com.br

${ }^{2}$ Doutoranda em Direito Constitucional - UFPE; Mestre em Direitos Humanos - UFPE; Especialista Direito Administrativo - UFPE; e, em Direito Público - ESMAPE.e-mail: livia.barrospe@gmail.com
} 


\section{INTRODUÇÃO}

Nos últimos anos, com o enfraquecimento do Poderes Legislativo e Executivo, decorrente da inércia inconstitucional e dos mais variados escândalos de corrupção, tem o Poder Judiciário uma crescente e ativa atuação na vida institucional brasileira, principalmente, o Supremo Tribunal Federal (STF).

O presente artigo possui como tema central o ativismo judicial e a repercussão midiática das decisões judiciais, principalmente as do STF, que faz a transmissão "ao vivo" dos julgamentos do plenário da Corte pela TV Justiça. O objetivo é analisar se, esta visibilidade pública, contribui para a transparência, para o controle social e para a democracia, ou se, em última análise, para um "enquadramento" das decisões com base nas motivações “ideológicas/ partidárias" dos membros da Corte. Será que o ganho é maior que a perda esta contribuição?

A Constituição de 1988, a chamada "Constituição Cidadã" têm no seu artigo $5^{\circ}$ dos direitos fundamentais Tais direitos, é base ensejadora e o ponto central do debate doutrinário sobre a questão do que confere legitimidade ao Poder Judiciário, notadamente ao STF, para decidir a respeito de questões polêmicas que ficaram à margem da discussão parlamentar e dos planos de governo. (CAVALCANTI, 2016). $\mathrm{O} \$ 1^{\circ}$ do art. $5^{\circ}$ da Carta Magna determina que as normas definidoras dos direitos e garantias fundamentais têm aplicação imediata. Além disso, o inciso XXXV do artigo $5^{\circ}$ aduz que a "a lei não excluirá da apreciação do poder judiciário lesão ou ameaça a direito" (BRASIL, 1988). Constata-se, portanto, que o nosso modelo constitucional obriga o Poder Judiciário à, sempre que provocado, agir no sentido de efetivar os direitos fundamentais quando estes sofrem a violação.

O texto constitucional consagra a Teoria da Tripartição dos Poderes, aduz em seu art. 2: "são Poderes da União, independentes e harmônicos entre si, o Legislativo, o Executivo e o Judiciário". O filosofo francês, Montesquieu (2000) atenta para o fato de que, em um Estado para que exista liberdade política, é imperioso que estes três poderes não estejam reunidos nas mãos de um único órgão ou um único homem. O Estado é uno e o poder é único. Portanto, quando se fala em separação de poderes, reporta-se a uma separação de funções estatais conferida a órgãos especializados para cada atribuição. O poder constituinte originário, como representante dos anseios e da soberania popular, atribuiu ao STF, precipuamente, a guarda da nova constituição (art. 102, CF).

Rev. de Teorias do Direito e Realismo Jurídico | e-ISSN: 2525-9601 | Maranhão | v. 3 | n. 2 | p. 1 - 19 | Jul/Dez. 2017. 


\section{A CRISE DA SEPARAÇÃO DOS PODERES E O “MIDIATISMO” DO JUDICIÁRIO BRASILEIRO: UMA ANÁLISE DOS RISCOS DEMOCRÁTICOS DE UM “SUPERPODER"}

Em um Estado de direito, a Constituição e as leis, a um só tempo, legitimam e limitam o poder político. Segundo Luís Roberto Barroso (2016), o ativismo judicial está longe de ser uma "ditadura de togas", é uma atitude, um modo proativo de interpretar a constituição. Já para Lenio Streck(2014), “a discricionariedade acaba, no plano da linguagem, sendo sinônimo de arbitrariedade".

Se perfaz, a inquietação: No Brasil o ativismo judicial ganha contornos que ultrapassam a legitimidade do Poder judiciário? Ou há riscos democráticos à supervalorização de um Poder do Estado (atualmente do judiciário) em detrimento do esvaziamento dos demais?

\section{A SEPARAÇÃO DOS PODERES E O NEOCONSTITUCIONALISMO}

Historicamente, a separação de poderes designa um dos pilares do Estado Democrático de Direito, está previsto no artigo $2^{\circ}$ da Constituição Federal de 1988 e constitui uma das cláusulas pétreas (artigo $60, \S 4^{\circ}$, III) do ordenamento jurídico brasileiro. Salienta-se que a característica de independência entre os órgãos do Poder Político (Legislativo, Executivo e Judiciário) consiste que um Poder caso necessite, pode valer-se em caráter excepcional e provisório, da função típica de outro Poder, para que se possa garantir o integral desempenho de suas próprias funções constitucionais.

O art. 16 da Declaração Francesa dos Direitos do Homem e do Cidadão, de 1789, dispunha que "toda a sociedade em que não esteja assegurada a garantia dos direitos nem estabelecida à separação dos poderes não tem Constituição", que sob influência liberalburguesa do fim século XVIII e do ideal da limitação jurídica ao poder estatal, demonstra a intrínseca vinculação entre os direitos fundamentais e as noções de Constituição e Estado de Direito, tornando-se, portanto, o núcleo material das primeiras Constituições escritas (SARLET, 2015).

No Brasil, o constitucionalismo esteve atravancado por mais de 20 anos em razão do período de ditadura militar iniciado em março de 1964. Apenas em 1985 deu-se início ao processo de redemocratização do país, que resultou, em $1^{\circ}$ de fevereiro de 1987, na instalação dos trabalhos da Assembleia Nacional Constituinte, que proporcionou um debate sem precedentes na história nacional com ampla participação da sociedade civil.

A Constituição Federal de 1988, além de garantir a institucionalização do regime 
político democrático, propiciou um grande avanço no que se refere à institucionalização e garantia dos direitos fundamentais, sendo então chamada de "Constituição cidadã" pelo, na época, deputado Ulysses Guimarães.

A partir de 1988, o Brasil trouxe para dentro de sua Constituição o reconhecimento dos direitos fundamentais, apresentando-os, inclusive, em seu preâmbulo como pressupostos do Estado Democrático de Direito:

Nós, representantes do povo brasileiro, reunidos em Assembléia Nacional
Constituinte para instituir um Estado Democrático, destinado a assegurar o exercício
dos direitos sociais e individuais, a liberdade, a segurança, o bem-estar, o
desenvolvimento, a igualdade e a justiça como valores supremos de uma sociedade
fraterna, pluralista e sem preconceitos, fundada na harmonia social e comprometida,
na ordem interna e internacional, com a solução pacífica das controvérsias,
promulgamos, sob a proteção de Deus, a seguinte Constituição da República
Federativa do Brasil (BRASIL, 1988, p. 1).

A positivação dos direitos e garantias fundamentais vai além da função limitadora de poder e passa a ser a base e o fundamento do próprio Estado de Direito que os institui, formando o que Canotilho (1992, p.114) chama de "reserva de justiça", a dizer, tais direitos e garantias apresentam-se como parâmetros de legitimidade em sentido formal e material da ordem jurídica estatal, proporcionando aos jurisdicionados enxergar os instrumentos necessários à garantia de liberdades e direitos que em conjunto com a ideia de soberania popular definem os pressupostos do Estado Democrático de Direito.

Nosso texto constitucional, contudo, não decorre apenas do processo interno de redemocratização, mas é um típico representante do fenômeno da recepção legislativa entendido como a introdução em um sistema jurídico de normas ou institutos de outro sistema. Isto, contudo, não representou um país real, mas onde gostaríamos de chegar, com influências de várias constituições estrangeiras, como a americana, francesa, portuguesa, italiana, alemã, espanhola e de países socialistas. Acrescenta Dantas (2014, p. 363):

A Constituição Brasileira não difere muito dos demais documentos contemporâneos, já que alarga a matéria constitucional, incorporando direitos fundamentais de caráter econômico, social e cultural, além de preocupar-se com a organização econômica da sociedade.

No âmbito da positivação dos direitos fundamentais presentes na Constituição Federal de 1988, ressaltam-se três inovações que demonstram claramente o grau de relevância empregado aos mesmos. Conforme Dantas (2011, p. 4-5):

I. Os direitos e garantias fundamentais foram geograficamente posicionados no texto constitucional em capítulo próprio, após o preâmbulo e os princípios fundamentais, o que traduz 


\section{A CRISE DA SEPARAÇÃO DOS PODERES E O “MIDIATISMO” DO JUDICIÁRIO BRASILEIRO: UMA ANÁLISE DOS RISCOS DEMOCRÁTICOS DE UM “SUPERPODER”}

maior rigor lógico na medida em que constituem parâmetros hermenêuticos e valores superiores de toda ordem constitucional e jurídica.

Ademais, a utilização da expressão "direitos e garantias fundamentais", em detrimento da expressão "direitos e garantias individuais", utilizada nas cartas constitucionais anteriores, demonstra a conformidade com a tradição do constitucionalismo na esfera dos direitos fundamentais.

II. Consagrou-se status jurídico diferenciado e reforçado aos direitos fundamentais, anteriormente reconhecidos em caráter meramente programático no capítulo da ordem econômica e social.

A partir de 1988, passaram a ter aplicabilidade imediata, em que pese o reconhecimento de equívocos em relação à técnica legislativa aplicada e a existência de lacunas, como da ausência de previsão de normas genéricas de proteção, a exemplo da proporcionalidade, que serviriam de elemento para um parâmetro científico e uniforme da matéria, como já amplamente aceito no âmbito do direito estrangeiro, nas Constituições alemã (1949), portuguesa (1976) e espanhola (1978) (SARLET, 2015, p. 75-81).

III. A maior proteção outorgada aos direitos e garantias fundamentais disposta no item 2 manifesta-se, ainda, mediante inclusão dos mesmos no rol das cláusulas pétreas (art. $60, \S 4^{\circ}$ $\mathrm{CF} / 88$ ), que impede a supressão e erosão dos preceitos relativos aos direitos fundamentais pela ação de poder de reforma.

Considerando a universalidade e indivisibilidade dos direitos humanos, a cláusula de proibição do retrocesso social, o valor da dignidade humana e demais princípios, também alcançam os direitos sociais as garantias de intangibilidade e irredutibilidade. Deste modo, o instrumento normativo que os afetarem ou os suprimirem, seja lei ordinária ou emenda à constituição, padecerá de vício de inconstitucionalidade.

$\mathrm{O}$ artigo $5^{\circ}$ da Constituição Federal, em seu parágrafo $2^{\circ}$ determina que os direitos e garantias fundamentais expressos na Constituição não excluem os demais, decorrentes do regime e dos princípios adotados, ou mesmo de tratados internacionais, reconhecendo, portanto, a existência de direitos fundamentais implícitos à norma, não-inscritos ou mesmo dispostos em outras partes do texto constitucional.

Do exposto, infere-se que em relação aos direitos fundamentais há uma relativa unidade de conteúdo, que juntamente com o princípio da aplicabilidade imediata das normas 
definidoras de direitos e garantias fundamentais, assim como com a inclusão no rol das cláusulas pétreas, podem ser considerados elementos caracterizadores da existência de um sistema relativamente autônomo no âmbito do próprio sistema constitucional que integra em que esta relatividade servirá de meio para a inter-relação com os demais dispositivos constitucionais, principalmente ao que se refere à ordem econômica e social.

Isto não quer dizer que os direitos e garantias fundamentais apresentam-se como um sistema fechado, separado do restante da Constituição, inclusive, em razão do $\S 2^{\circ}$ do art. $5^{\circ}$, supracitado que demonstra ser este um conceito aberto e flexível, receptivo a novos conteúdos.

Após a Constituição de 1988, outro elemento do constitucionalismo pretérito apresentou necessidade de reavaliação em razão de não mais corresponder aos anseios sociais: a ideia de separação rígida entre os Poderes, cabendo, portanto, ao Judiciário entender e atuar na guarda da Constituição, tanto numa perspectiva negativa de defesa, como positiva e prestacional, inclusive, no preenchimento de lacunas. Como explana Neves (2006, p. 19):

\begin{abstract}
Nesse tipo de Estado, Têmis deixa de ser um símbolo abstrato de justiça para se tornar uma referência real e concreta de orientação da atividade de Leviatã. Este, por sua vez, é rearticulado para superar sua tendência expansiva, incompatível com a complexidade sistêmica e a pluralidade de interesses, valores e discursos da sociedade moderna. Não se trata apenas de uma fórmula para 'domesticar' ou 'domar' o Leviatã. Antes, o problema consiste em estabelecer, apesar das tensões e conflitos, uma relação construtiva entre Têmis e Leviatã.
\end{abstract}

Como bem esclarece Lins (2009, p.68), ao mesmo tempo em que a noção de separação de poderes vem sendo desafiada e se impõe uma reinvenção conceitual, por outro lado, ela deixa de ser apenas um mecanismo de afirmação de direitos, alcançando-se um sistema de preservação da própria democracia.

Nesse sentido, acatamos a posição defendida por Dantas (2014) em que não há comprometimento ao conceito de Democracia, a afirmação da legitimidade do controle positivo realizado pelo judiciário, visto que assim como os demais poderes, decorre da própria Constituição Federal:

Em nosso entender, não há nenhum comprometimento ao conceito de Democracia, o fato de haver controle sobre a produção legislativa levada a efeito por órgão composto por "representantes do povo", até porque, no fundo, o controle de constitucionalidade visa salvaguardar a vontade expressa no documento fundante de uma sociedade, em determinado momento histórico. Dizendo melhor e como temos escrito em diversas oportunidades: a Constituição Político-Jurídica é um documento que resulta de um consenso oriundo das diversas forças políticas presentes na Assembléia Constituinte no ato de elaboração do texto maior. Ora, em sendo assim, este texto foi feito para balizar o exercício do poder, mesmo quando existam forças eventualmente majoritárias que queiram substituir a orientação ideológica da Lei Maior. A verificação desta 


\section{A CRISE DA SEPARAÇÃO DOS PODERES E O “MIDIATISMO” DO JUDICIÁRIO BRASILEIRO: UMA ANÁLISE DOS RISCOS DEMOCRÁTICOS DE UM “SUPERPODER"}

compatibilização há de ser feita de forma técnica, o que justifica seja o Controle exercido por Magistrados sem vinculação político-partidária. Sua legitimidade é decorrente da própria Constituição, ou seja, é funcional (DANTAS, 2014, p. 22-23).

O que não se trata de conferir ao Judiciário a possibilidade de definição de políticas públicas, principalmente no que tange à efetivação de direitos como saúde e educação, mas de se adentrar numa fase mais crítica e criteriosa dos Direitos Fundamentais Sociais, desmistificando estes, sobre o que se pode ou não creditar à eficácia judicializável dos direitos sociais (BARROSO, 2009).

A Constituição de 1988, aprovada num contexto econômico e social difícil, faz clara opção pela democracia e sonora declaração em favor da superação das desigualdades sociais e regionais. Precisamos expandir a capacidade do Estado social de se desenvolver e buscar a concretização efetiva dos direitos sociais por meio da afirmação das liberdades.

Passado o momento inicial de compreensão do sentido da Constituição Republicana de 1988, o constitucionalismo brasileiro passou a buscar critérios, não mais para negar eficácia aos direitos fundamentais, referindo-se a esses direitos como meras normas pragmáticas, mas discutindo uma dogmática constitucional capaz de atender aos conflitos decorrentes de sua práxis.

A mudança social não se alcança automaticamente após a constitucionalização de um direito, pois dependerá de uma política legislativa própria. Como já apresentado no início do presente trabalho, o problema dos direitos humanos fundamentais, dentre eles, o direito à saúde, não é mais o reconhecimento normativo/constituição, em que pese à baixa hierarquia das normas que regulamentam o caso do direito à saúde, e, sim, sua efetividade.

Com o objetivo de facilitar a compreensão do caminho percorrido em busca da efetividade dos direitos fundamentais, no que diz respeito ao aspecto dogmático e não históricoinstitucional, elaboramos um breve inventário acerca da positividade dos direitos, fundamentais conforme, Galdino (TORRES et al, 2007):

I. Modelo teórico da indiferença: a produção teórica original, predominante europeia, reflexo da orientação política libertária e liberal (a exemplo da Revolução Francesa de 1789), de viés jusnaturalista.

Esse modelo não considerava a necessidade de prestações estatais positivas para a efetivação de direitos públicos subjetivos, ou sobre a relevância do conteúdo econômico dos direitos individuais, de sorte que os direitos de liberdade, inerentes ao homem, eram vistos como 
anteriores e superiores ao Estado, de forma que este apenas os declara, não havendo espaço para discutir-se prestações estatais necessárias à efetivação.

II. Modelo teórico do reconhecimento: sob influência dos movimentos intelectuais de esquerda, da Igreja, especialmente da teologia da libertação, bem como da crescente necessidade de intervencionismo estatal.

Nesse modelo, ocorre o reconhecimento da juridicidade de determinadas situações subjetivas previstas na Constituição em favor dos indivíduos. Assim, há o reconhecimento dos direitos fundamentais sociais, como aqueles que necessitam de uma atuação positiva do Estado para sua efetivação, sem, contudo, haver a vinculação quanto à exigibilidade imediata de tais direitos.

Segundo Moraes Filho (CAVALCANTI, 1977, p. 179):

\begin{abstract}
O que por outro lado distingue os direitos sociais da antiga declaração dos direitos do homem e do cidadão é o fato da verdadeira posição de base conceitual. Estes segundos são limitativos dos poderes do Estado, limitam-lhe o arbítrio, cercando-o de certas liberdades e franquias dos indivíduos como cidadãos isolados. São direitos de caráter negativista, em relação aos poderes públicos, fiéis ao próprio espírito individualista das revoluções dos fins do século XVIII. Os primeiros - direitos sociais - são garantias positivas, inscritas no texto constitucional, em favor dos grupos sociais, da sociedade e de suas manifestações. O papel do Estado aqui não é negativista, de absteísmo, de omissão; pelo contrário, manifesta-se concretamente, intervindo em favor de certas realizações materiais ou culturais. $\mathrm{O}$ seu papel é ativo, e não mais passivo, de mero espectador. Tudo isso acompanhou o próprio desenvolvimento da legislação social ordinária, rompendo com o tradicional individualismo jurídico, egoísta, regulado simplesmente pelas normas do direito civil. Pela nova realidade econômico-social, já com medidas concretas de intervenção estatal, somente faltava dar mais um passo para atingir a esfera mais elevada da constitucionalização daquela legislação.
\end{abstract}

III. Modelo teórico da utopia: a positividade dos direitos sociais permanece reconhecida, contudo, há o desprezo quanto ao custo da efetividade dos mesmos.

Funda-se na premissa de que o déficit orçamentário público é uma imposição da necessidade da atuação governamental eficiente, em que não há limite às prestações públicas, que caracterizam o Estado Social ou o Bem-estar Social.

Neste momento, na medida em que não faltariam recursos, negava-se relevância, do ponto de vista prático, entre direitos positivos ou negativos, isto porque o país vivia sob um status político autoritário, acrescido da recepção tardia das ideias originais de Hans Kelsen, que resultou num positivismo exacerbado, em que as questões jurídicas reduziram-se à norma, em especial, à regra positivada.

A questão era saber se a norma previa ou não um determinado direito, e em que extensão. Os custos financeiros são vistos como absolutamente externos ao conceito do direito, 


\section{A CRISE DA SEPARAÇÃO DOS PODERES E O “MIDIATISMO” DO JUDICIÁRIO BRASILEIRO: UMA ANÁLISE DOS RISCOS DEMOCRÁTICOS DE UM “SUPERPODER"}

de tal sorte que o reconhecimento dos direitos subjetivos fundamentais precede e independe de qualquer análise relacionada às possibilidades reais de sua concretização.

IV. Modelo teórico da verificação da limitação dos recursos: o custo assume caráter fundamental, de tal arte que, mantida a tipologia direitos positivos x direitos negativos, tem-se a efetividade dos direitos sociais como sendo dependente da reserva do possível.

Superando os paradigmas de déficit orçamentário necessário, o país foi conduzido à revisão das despesas públicas deficitárias, sustentando que as normas devessem limitar-se à receita do Estado. O principal objetivo a ser alcançado é o equilíbrio orçamentário.

O estado social não desaparece, mas renova-se influenciado pelo liberalismo social, como menciona Torres (1995, p. 15):

\footnotetext{
Mas na verdade é que o modelo do Estado social não desaparece totalmente. Passa por modificações importantes, com a diminuição do seu tamanho e a restrição ao seu intervencionismo. Deixa-se influenciar pelas ideias do liberalismo social, que não se confundem com as do neoliberalismo ou do protoliberalismo nem, por outro lado, com as da social-democracia. Continua a ser Estado Social Fiscal, podado em seus excessos, ao fito de obter a síntese entre o que os alemães chamam de Estado de Impostos (Steuerstaat) e Estado de Prestações (Leistungstaat).
}

Assim sendo, a realidade finalmente projeta raios de luz sobre o antes fechado pensamento jurídico e seu produto, o mundo jurídico. Passou-se a admitir que a impossibilidade material faça com que a dicção normativa ganhe mais significado do ponto de vista prático; contudo, sem abandonar seu caráter pragmático, fruto de sua inegável dimensão prospectiva e da otimização de sua função negativa, no sentido de impedir o legislador de adotar medidas que sejam contrárias a determinado programa constitucional, ou permitindo o reconhecimento da nulidade nos casos em que forem adotadas (BARROSO, 2009).

Segundo Bobbio (2014) no ordenamento jurídico, as normas editadas pelo Poder Originário, regulam o comportamento das pessoas, regulam ainda, o modo com qual se devem produzir as "regras do jogo político."

Diante disto, podemos afirmar que, com efeito, até a Segunda Guerra Mundial, o judiciário não tinha muita discricionariedade, era simplesmente, a "Boca da lei". O termo "neoconstitucionalismo" está intimamente ligado a ruptura com o "modos operandi" do positivismo jurídico pós Segunda Guerra. É o direito "pós-Auschiwitz”.

No Brasil, o Neoconstitucionalismo nasceu com a redemocratização em 1988, outorgando força normativa dos princípios constitucionais, que até então fora esquecido. Além 
da, predominância dos direitos fundamentais, nascendo a necessidade de "uma nova interpretação constitucional".

Vemos assim, a ascensão institucional do Judiciário com o uso da jurisdição constitucional. A divergência doutrinaria sobre o neoconstitucionalismo é grande. Para Barroso (2016, p.3):

O neoconstitucionalismo ou novo direito constitucional, identifica um conjunto amplo de transformações ocorridas no Estado e no direito constitucional, em meio às quais podem ser assinalados, (i) como marco histórico, a formação do Estado constitucional de direito, cuja consolidação se deu ao longo das décadas finais do século XX; (ii) como marco filosófico, o pós-positivismo, com a centralidade dos direitos fundamentais e a reaproximação entre Direito e ética; e (iii) como marco teórico, o conjunto de mudanças que incluem a força normativa da Constituição, a expansão da jurisdição constitucional e o desenvolvimento de uma nova dogmática da interpretação constitucional. Desse conjunto de fenômenos resultou um processo extenso e profundo de constitucionalização do Direito.

Segundo Streck (2014, p.13-14), o "fruto" desta nova estrutura nos levaria a uma

patologia de corrupção do texto constitucional. (Mutação constitucional):

É um equívoco utilizar a nomenclatura "neoconstitucionalismo", prefere o termo Constitucionalismo Contemporâneo, que pode ser concebido como um movimento teórico jurídico-político em que se busca limitara o exercício do poder a partir da concepção de mecanismos aptos a gerar e garantir o exercício da cidadania. $\mathrm{Na}$ verdade, conduz simplesmente a um processo de continuidade com novas conquistas, que passam a integrar a estrutura do Estado constitucional no período posterior a Segunda Guerra Mundial.

Segundo Barroso (2014, p.4), “a Constituição faz a interface entre o universo político e o jurídico, instituindo o Estado de direito, os poderes constituídos e fazendo a distinção entre legislar, administrar e julgar. "

O que dá ensejo ao Ativismo judicial, abordado no próximo tópico.

\section{ATIVISMO JUDICIAL E O SUPREMO TRIBUNAL FEDERAL}

Já é uma tarefa difícil a tentativa de formação do conceito de ativismo judicial, tendo em vista que a definição do termo por vezes, está ligada ao combate de posicionamento ideológicos entre autores. O conceito de ativismo judicial surge com uma conotação marcada negativamente, no contexto histórico-político americano. No brasil, o conceito ainda denota tal negatividade.

O ativismo judicial surgiu nos Estados Unidos com a publicação do artigo "The 


\title{
A CRISE DA SEPARAÇÃO DOS PODERES E O “MIDIATISMO” DO JUDICIÁRIO BRASILEIRO: UMA ANÁLISE DOS RISCOS DEMOCRÁTICOS DE UM “SUPERPODER”
}

Supreme Court:1947” na Revista Fortune, no ano de 1947 de autoria do jornalista Arthur Schlesinger Jr. Em que analisou a atuação dos justices, distinguindo-os entre "ativistas" (activists) e "campeões da restritividade judicial" (champions of judicial restraint), os quais podem ser denominados "passivistas" (self-restrain). Segundo Sunstein:

\begin{abstract}
Aqueles se caracterizariam por inocularem, em suas decisões, as suas próprias concepções do bem comum. Os passivistas, por sua vez, seriam os juízes que procuravam preservar a margem de conformação do legislador, prezando pela maior deferência judicial. O que se conclui, desde logo, é que o ativismo encerra um juízo negativo sobre o exercício da jurisdição constitucional, já que o campo semântico do conceito de ativismo judicial corresponderia a um verdadeiro "insulto" (CONTINENTINO,2012 APUD SUNSTEIN, 2003)
\end{abstract}

O ativismo judicial poderia ser uma "aberração jurídica", ao ponto de infringir o próprio princípio da segurança jurídica. Nas palavras de Barroso (2016, p. 7):

O ativismo judicial é uma atitude, a escolha de um modo específico e proativo de interpretar a Constituição, expandindo o seu sentido e alcance. Normalmente ele se instala em situações de retração do Poder Legislativo, de um certo descolamento entre a classe política e a sociedade civil, impedindo que as demandas sociais sejam atendidas de maneira efetiva

O principal argumento a favor do ativismo é que, diante da omissão dos demais Poderes, que falham na efetivação dos direitos fundamentais, cabe ao Poder Judiciário, como guardião da Constituição, garantir sua efetividade. O ativismo caracteriza-se por um modo proativo e criativo de interpretação constitucional. Ou seja, torna-se mais razoável realizar uma releitura da norma, a fim de adequá-la à nova realidade, sem ter que reformar a Constituição "apenas para inserir e/ou retirar uma palavra".

Várias são as críticas quanto a esta "atitude", destacamos aqui, a que configura uma "pedra no sapato" de todos os doutrinadores brasileiros: o problema da legitimidade democratica da ação ativa do Judiciário. Segundo Bonavides (2016, p. 02), "toda a legitimidade em matéria constitucional é mais política que jurídica. ” E assevera:

A legitimidade dos tribunais constitucionais é antes de tudo, pura e simplesmente, a legitimidade da própria constituição.

Para Lassale (2016, p.5), os problemas constitucionais não são problemas de direito, mas do poder. E a validade da Carta, é sua fiel representação aos fatores do poder que vigoram na realidade social.

Tem em conta que, juízes e membros dos tribunais não são agentes públicos eleitos. Sua investidura não tem o batismo da vontade popular. Essa possibilidade de as instâncias 
judiciais sobreporem suas decisões às dos agentes políticos eleitos gera aquilo que em teoria constitucional foi denominado de dificuldade contramajoritária.

Agrava- se ao fato que, no Pretório Excelsior, o órgão de cúpula judiciária brasileira, seus membros serem indicados pelo Presidente da República, o que implicaria em uma "submissão política" dos seus indicados. O Supremo Tribunal Federal é composto por onze Ministros, brasileiros natos (art. 12, § $3^{\circ}, \mathrm{IV}$, da CF/88), escolhidos dentre cidadãos com mais de 35 e menos de 65 anos de idade, de notável saber jurídico e reputação ilibada (art. 101 da CF/88), e nomeados pelo Presidente da República, após aprovação da escolha pela maioria absoluta do Senado Federal.

Por fim, seguindo os ensinamentos de Streck: "ativismo constitui um ato de vontade daquele que julga, isto é, caracterizando uma ‘corrupção' na relação entre poderes, na medida em que há uma extrapolação dos limites na atuação do judiciário pela via de uma decisão que é tomada a partir de critérios não jurídicos. " Podemos afirmar que, as críticas se concentram nos riscos para a legitimidade democrática, na politização indevida da justiça e nos limites da capacidade institucional do Judiciário.

O STF, na história brasileira mantinha certa discrição institucional até 1988. Com um frágil sistema de fiscalização de constitucionalidade e sem efetiva democracia. Desempenha um papel, até certo ponto de "coadjuvante" no cenário político nacional. Podemos dizer, que era um mero "enfeite" dentro do longo período de regime de exceção no país.

Hoje, a realidade é bem distinta. Nos últimos 15 anos, tem protagonizado, cada vez mais incisivamente na vida política, que via de regra, não é ruim. Diversos são os exemplos de ativismo na Corte. Em entrevista o Ministro aposentado Antonio Cezar Peluso ao ser questionado sobre o ativismo judicial no Supremo Tribunal Federal declarou que:

O Supremo sempre aponta para os interesses gerais da sociedade. Essa acusação de ativismo não é exclusiva da Suprema Corte do Brasil. Nos EUA, sérios problemas que deveriam ter sido resolvidos no plano legislativo, ou na área administrativa, só tiveram solução social satisfatória com a intervenção da Suprema Corte. Foi assim inclusive com o racismo. No Brasil lidamos comuma Constituição Analítica, bem diferente da Americana, com seus poucos artigos. A nossa Carta cuida de uma série de matérias que poderiam ser regidas por lei ordinária. E isso tem explicação: A Constituição de 88 foi editada após longo período de autoritarismo, quando os constituintes resolveram regular tudo. Daí o Supremo ser acionado, ele decide. Isso já foi chamado de "ativismo judicial a convite constitucional", o que é apropriado. Só que o Supremo não dá motivos para acusações de partidarismo. Mesmo lidando com questões políticas, age com independência, ao contrário do que se ouve falar de outras cortes. Eu diria mais: quando decisões da Corte chama a atenção da opinião pública é porque as matérias tratadas representam divisões dentro da sociedade brasileira. Falo de temas como o aborto, células-tronco, fetos anencéfalos, direitodos homoafetivos. (PELUSO, 2016.p.3) 


\section{A CRISE DA SEPARAÇÃO DOS PODERES E O “MIDIATISMO” DO JUDICIÁRIO BRASILEIRO: UMA ANÁLISE DOS RISCOS DEMOCRÁTICOS DE UM “SUPERPODER"}

A falta de "credibilidade" dos demais Poderes, faz com que a população veja no judiciário, uma solução mais eficiente dos seus problemas. O STF, não tem culpa de essas questões a ele serem submetidas. Todavia, tem-se percebido que suas decisões acabam sendo estritamente política. Nota-se que o emprego do ativismo judicial é justificado na necessidade de dar efetividade às normas constitucionais. Como salienta o doutrinador Lenio Streck: "em uma democracia constitucional é necessário que exista um judiciário forte, que funcione como efetivo garantidor dos direitos fundamentais" e das regras do jogo constitucional.

Alguns exemplos do ativismo criativo do STF nos últimos anos: Vedação do nepotismo nos três poderes (ADC 12, Rel. Min. Carlos Britto; e RE 579.951/RN Rel. Min. Ricardo Lewandowski); Demarcação de terras indígenas na área conhecida como raposa/serra do sol (Pet. 3388/RR, Rel. Min. Carlos Britto). Súmulas Vinculantes; Interrupção de gestação no caso de anencefalia (ADPF 54); Constitucionalidade das pesquisas com células-tronco embrionárias (ADIn 3.510/DF, Rel. Min. Carlos Britto); Prisão por dívida. Virada na jurisprudência (HC's 87.585/TO, Rel. Min. Marco Aurélio e 92.566, Rel. Min. Marco Aurélio; RE’s 349.703, Rel. p/ ac. Min. Gilmar Mendes e 466.343, Rel. Min. Cezar Peluso); Inelegibilidade e vida pregressa de candidatos a cargos eletivos (ADPF 144/DF, Rel. Min. Celso de Mello).

Não há como negar a presença do ativismo judicial na atuação do Supremo, mas alguns fatos são causas ensejadoras para isto. Por ser um produto humano, o direito participa das vicissitudes da ação social. "Nunca será isenta de valoração e de ideologia." (PORTANOVA, 2003. p.4). Destacamos os principais fatores:

a) A judicialização da política e das relações sociais: Judicialização não se confunde com ativismo judicial, afirma Barroso; em participação em uma conferência mundial representando o Brasil, o ministro e professor Luís Roberto Barroso sustentou que as cortes constitucionais em geral, e o Supremo Tribunal Federal em particular, desempenham três papéis distintos: contramajoritário, representativo e iluminista. Observou que, apesar de o nível de judicialização no país ser elevado, o número de leis federais declaradas inconstitucionais é reduzido.

Considera-se como causas desta Judicialização Para Barroso (2016), Judicialização significa que questões relevantes do ponto de vista político, social ou moral estão sendo decididas, em caráter final, pelo Poder Judiciário. Trata-se, como intuitivo, de uma transferência de poder para as instituições judiciais, em detrimento das instâncias políticas 
tradicionais, que são o Legislativo e o Executivo. Constitucionalizar é, em última análise, retirar um tema do debate político e trazê-lo para o universo das pretensões judicializáveis

No Brasil, como assinalado, a judicialização decorre, sobretudo, de dois fatores: o modelo de constitucionalização abrangente e analítica adotado; e o sistema de controle de constitucionalidade vigente entre nós, que combina a matriz americana - em que todo juiz e tribunal pode pronunciar a invalidade de uma norma no caso concreto - e a matriz europeia, que admite ações diretas ajuizáveis perante a corte constitucional. Ou seja, a judicialização está intrinsicamente ligada a ascensão do Poder Judiciário.

b) Omissão do Poder Legislativo e do Executivo e o Princípio da Inafastabilidade Jurisdicional: esta é, sem sombra de dúvida, a principal causa do ativismo hoje no Brasil, sendo o STF, o guardião da Constituição e um “zelador" da ordem constitucional quando a mora dos demais Poderes põem em risco a efetivação dos direitos fundamentais dos cidadãos. Conforme afirma Barroso, eis o "momento legitimador" da atuação do judiciário. Tendo em vista que, uma vez provocado, não se pode alegar a inexistência da lei para a não prestar a jurisdição constitucional. Os representantes do judiciário podem, e devem tomar decisões a fim de suprimir eventuais lacunas legislativas, pois, no exercício da prestação jurisdicional, tem-se no juiz a própria face do Estado. É ilusório e utópico afirmar que é um país democrático, sem que se haja uma providencia concreta para que a liberdade pública saia do papel. Em suma: a reiterada omissão estatal, na garantia dos direitos fundamentais, é muito mais grave do que a intervenção do Poder Judiciário para a efetivação destes direitos violados.

c) A interpretação jurídica e suas complexibilidades: já é uma discussão doutrinaria antiga, já falava na década de 60 o ilustre jurista Noberto Bobbio (2014), que o ordenamento jurídico se pretende perfeito, contudo, não o é. Suas lacunas e ambiguidades, sua vagueza epistemológica, sua complexidade, enfim vários são os “erros” encontrados neste ordenamento. Exemplificam-se aqui: (i) A linguagem aberta dos textos jurídicos; (ii) os desacordos morais, visto que, os signos precisam ser interpretados, e a interpretação envolve uma semântica de sentido de norma com base em uma sociedade pluralista e diversificada; (iii) as colisões das normas constitucionais, dando azo a uso da ponderação; vemos assim a base que se tem chamado como "casos difíceis" (hard cases).

Em todas estas hipóteses de casos difíceis, o sentido da norma precisará ser fixado pelo juiz. Aí é que reside o “x” da questão, conforme assevera Lenio Streck(2014), pois dá azo 


\section{A CRISE DA SEPARAÇÃO DOS PODERES E O “MIDIATISMO” DO JUDICIÁRIO BRASILEIRO: UMA ANÁLISE DOS RISCOS DEMOCRÁTICOS DE UM “SUPERPODER”}

para que o resultado da decisão esteja baseado não no princípio, mas no fim, no resultado. É linha tênue entre a politização do direito. Pois, como humanos que são, os juízes não estão imunes ideologias, paixões assim como pretendia Kelsen. Decisões judiciais refletem as preferências pessoais dos juízes e são essencialmente políticas. E isso é um grande perigo para o Estado Democrático de Direito.

d) A influência da mídia nas decisões judiciais: para alguns dos doutrinadores, a Mídia pode ser considerada um "quarto Poder", pela tamanha influência que gera na vida não só política, como econômica, educacional, enfim, nos mais diversos setores do país. $\mathrm{O}$ que, de forma geral, não é de todo ruim nem bom. Vivemos em uma democracia jovem, são apenas 28 anos de "liberdade de expressão", foram anos repressão.

Não havia publicidade, tanto que em 1968, foi escrito a obra: O Supremo Tribunal Federal, esse outro desconhecido pelo Min. Aliomar Baleeiro, obra esta, que tenta explicar o que é essa Corte. Entretanto, tem-se hoje, um STF atuando de "portas abertas", os julgamentos em plenário são divulgados maciçamente. As principais decisões e as reuniões do Pleno da Corte, são transmitidas por canal Televisivo próprio (a TV Justiça) e também em sitio próprio na Rede Mundial de Computadores, para que todos acompanhem o que acontece, como pensam e o que se decide aqui, em "terrae brasiles". Nota-se, contudo que, tal publicidade não gera uma "preocupação" nos Ministros, pois é notório que na maioria das vezes, estes não decidem conforme o que é "justo", mas, conforme a "opinião pública" acredita ser melhor. Para Luís Barroso (2014,p.13):

Muitas vezes, a decisão correta e justa não é a mais popular. E o populismo judicial é tão ruim quanto qualquer outro. Um tribunal digno desse nome não pode decidir pensando nas manchetes do dia seguinte ou reagindo às do dia anterior.

$\mathrm{Na}$ atual composição do Supremo, temos 5 dos 11 ministros indicados pela ex Presidente da República, Dilma Rousseff. Outros 3 indicados pelo ex Presidente da República Luiz Inácio Lula da Silva. Quero com isto, demonstrar que, dos últimos 14 anos, a grande pressão popular com grande influência da mídia, em torno de tais ministros demonstraram em suas decisões uma certa tendência governista. Que seria uma total politização do Direito.

Nos dias atuais podemos acompanhar uma verdadeira crise institucional nos poderes da República. Entre os meses de março a outubro, vimos vários depoimentos dos juízes em questionamento ao Poder legislativo. Frisa-se o caso da Operação da Polícia Federal, 
denominada "Lava-Jato", tendo o juiz federal do Estado do Paraná, Sergio Moro um papel significativo na crítica brasileira, quando em 16 de março de 2016, divulgou que retirou o sigilo de interceptações telefônicas do ex- presidente Luiz Inácio Lula da Silva.

As conversas gravadas pela Polícia Federal incluem diálogo desta quarta com a presidente Dilma Rousseff, que o nomeou como ministro chefe da Casa Civil. O caso fez com que a então presidente não pudesse nomear o chefe da casa civil. Gerou protesto em todo o país, além de mobilizar um certo número de legisladores a entrar com pedidos no STF para verificar a legitimidade da nomeação, que tem por base constitucional a discricionariedade do presidente. Tal atitude provocou um debate doutrinário, até que ponto a arbitrariedade judicial pode ir? Em entrevista, o advogado de Luiz Inácio Lula da Silva, Cristiano Zanin Martins (2016, p.2), disse que:

\footnotetext{
Um grampo envolvendo a presidência da república é um fato muito grave. Esse ato está estimulando uma convulsão social. Isso não é papel do Poder Judiciário", disse Zanin na porta do Instituto Lula, onde o ex-presidente, nomeado nesta quarta ministro da Casa Civil, ficou reunido até por volta de 20h15. "A arbitrariedade independe do conteúdo do grampo. Esse grampo envolvendo uma presidência da República ser divulgado hoje quando não existe competência da vara de Curitiba revela finalidade que não é a processual.
}

Tal exemplo, está baseado em um juiz de primeira instância paranaense. Em âmbito do STF, temos noticiais recentes, ainda em andamento é o caso do Presidente do Senado, Renan Calheiros e a Presidente do Supremo, Min. Cármem Lúcia. Envolve as declarações feitas no último dia 24/10/2016 em decorrência da prisão de 4 policiais legislativos presos na “Operação Lava-Jato”, em coletiva a imprensa, o senador afirma: 'juizeco' de primeira instância não pode 'atentar contra um poder'. Policiais legislativos foram presos sob acusação tentar obstruir a Lava Jato. No dia 25/10/2016 a Min. Cármem Lúcia, em abertura de sessão da Comissão Nacional de Justiça- CNJ sai em defesa do Poder Judiciário, em resposta àsdeclarações do dia anterior voltou a afirmar que em uma democracia o juiz é essencial, como são essenciais os membros de todos os outros poderes. Mas, que também exige o mesmo e igual respeito para que se tenha uma democracia fundada nos princípios constitucionais, nos valores que nortearam não apenas a formulação, mas a prática da Constituição.

O que se pode afirmar diante deste quadro é que, os juízes não estão tão enraizados nos princípios gerais do direito. São meros "atores" das manchetes de jornais. Estamos à mercê da "onda" de popularidade e "estrelismos" dos Poderes.

Contudo, não é de todo ruim o uso da mídia, cujo uso deve ser eventual e controlado. 


\section{A CRISE DA SEPARAÇÃO DOS PODERES E O “MIDIATISMO” DO JUDICIÁRIO BRASILEIRO: UMA ANÁLISE DOS RISCOS DEMOCRÁTICOS DE UM “SUPERPODER”}

\section{CONCLUSÃO}

A expansão do Judiciário envolve certa desilusão com a política majoritária, em razão da crise de representatividade e de funcionalidade dos parlamentos em geral. No sentido de garantir uma prestação jurisdicional mais eficaz, diante da inercia dos demais poderes, “autorizamos" o Judiciário a agir a fim de suprir as lacunas legislativas. Como guardião da Constituição, não seria permitido ao Supremo Tribunal Federal deixar de zelar pelo respeito as moras constitucionais.

Em concordância com Paulo Bonavides (2016) destacamos que o judiciário o Judiciário brasileiro parece "flutuar" diante de pressões cujas ondas o fazem oscilar entre a cidadania e o capital, entre a independência e a submissão, entre a lei e o arbítrio, entre a razão e a vontade, entre o princípio e a regra, entre a democracia e o elitismo. A Constituição que ele tem por dever guardar perde cada dia que passa legitimidade e juridicidade. Isso acontece porque o País já não confia na retidão dos três Poderes no tocante ao desempenho de suas atribuições constitucionais. A desconfiança gera a crise e a enfermidade do sistema, e esta lhe poderá ser fatal.

Nos ensinamentos de Hesse (1991) a norma constitucional não tem existência autônoma em face a realidade. A força normativa da constituição depende não apenas do seu conteúdo, mas também de sua práxis. No que se refere ao "midiatismo" fica demonstrado que, tornaram-se "atores" do populismo, gerando a politização do direito.

Considerando que a produção normativa do intérprete não é produzida apenas a partir de elementos que se desprendem do texto, mas a partir da realidade concreta e do momento histórico no qual se opera sua interpretação, sem prejuízo da análise da interpretação já realizada até aquele momento histórico por outros atores jurídicos (GRAU, 2013), tratamos de trazer ao texto uma análise de caráter exploratório acerca de dados que se evidenciaram na elaboração do estudo quantitativo, relativos às estratégias argumentativas utilizadas pelos magistrados para ora deferir, ora indeferir medidas de urgência configuradas por circunstâncias análogas.

As Consequências do ativismo podem ser: (i) a instauração da ditadura judicial das inconstitucionalidades; (ii) A admissão de duas constituições uma formal outra 
jurisprudencial; (iii) se decidem bem, garante os direitos fundamentais. Se decidem mal, dá um passo para a ditadura dos juízes.

Dentro do questionamento levantado no presente artigo, não se pretende exauri o assunto. Percebe-se, contudo, que, é inegável que o Brasil não consegue efetivar o que prescreve a Carta Magna no que tange a proteção dos direitos fundamentais. Nessa perspectiva, o ativismo judicial se manifesta como uma realidade nacional, sendo que alguns autores o defendem, enquanto outros os condenam. Em suma, o ativismo judicial em si, é ambíguo. Não se pode em regra afirmar que é bom ou ruim. Precisamos de reforma política. E essa não pode ser feita por juízes.

\section{REFERÊNCIAS}

BARROSO, Luis Roberto. O direito constitucional e a efetividade de suas normas: limites e possibilidades da Constituição brasileira. 9. ed. Rio de Janeiro: Renovar, 2009.

. Judicialização, ativismo judicial e legitimidade democrática.

<file:///C:/Users/aluno.piic/Downloads/JUDICIALIZA\%C3\%87\%C3\%830,\%2 0ATIVISMO\%20JUDICIAL\%20E\%20LEGITIMIDADE\%20\%20DEMOCR\%C3\%81TICA. pdf $>$. Acessado em:29/10/2016.

. Neoconstitucionalismo e constitucionalização do Direito. $O$ triunfo tardio do DireitoConstitucional no Brasil. < https://jus.com.br/artigos/7547/neoconstitucionalismo-econstitucionalizacao-do-direito >. Acessado em 29/10/2016.

BRASIL. Constituição da República Federativa do Brasil de 1988. Disponível em: <http://www.planalto.gov.br/ccivil_03/constituicao/constituicaocompilado.htm>. Acesso em: 15 maio 2015.

BOBBIO, Noberto. Teoria do Ordenamento Jurídico. São Paulo: EDIPRO, $2^{\circ}$ Ed. 2014.

BONAVIDES, Paulo. Jurisdição constitucional e legitimidade (algumas observações sobre o Brasil). <http://www.scielo.br/pdf/ea/v18n51/a07v1851.pdf >. Acessado em: 29/10/2016.

CANOTILHO, Joaquim José Gomes. Direito constitucional. 5. ed. Coimbra: Livraria Almedina, 1992.

CAVALCANTE FILHO, João

Trindade.<http://www.stf.jus.br/repositorio/cms/portaltvjustica/portaltvjusticanoticia/anexo/j oatrindadadeteoriageral_dos_direitos_fundamentais.pdf >. Acessado em: 30/10/2016. 


\section{A CRISE DA SEPARAÇÃO DOS PODERES E O “MIDIATISMO” DO JUDICIÁRIO BRASILEIRO: UMA ANÁLISE DOS RISCOS DEMOCRÁTICOS DE UM "SUPERPODER"}

CONTINENTINO, Marcelo Casseb. Ativismo judicial: Proposta para uma discussão conceitual<https://www2.senado.leg.br/bdsf/bitstream/handle/id/496562/000940652.pdf?seq uence $=1>$ Acessado em 26/10/2016.

DANTAS, Ivo. Constituição \& processo. 2. ed. rev. atual. e ampl. Curitiba: Juruá, 2012. 2014. Instituições de direito constitucional brasileiro. 3. ed. rev. e atual. Curitiba: Juruá,

GRAU, Eros. Porque tenho medo dos juízes? (a interpretação/aplicação do direito e os princípios). São Paulo: Malheiros, 2013.

HESSE, Konrad. A força normativa da Constituição. Porto Alegre: Sérgio Antonio Fabris Editor, 1991.

LASSALE, Ferdinand. O que é uma constituição?

<http://www.ebooksbrasil.org/adobeebook/constituicaol.pdf > Acessado em: 30/10/2016.

LINS, Liana Cirne. A justiciabilidade dos direitos fundamentais sociais. Uma avaliação crítica do tripé denegatório de sua exigibilidade e da concretização constitucional seletiva. Revista de Informação Legislativa. Brasília, ano 46, n 182, abr.jun. 2009. p. 51-74.

MARTINS, Cristiano Zanin. <http://g1.globo.com/sao-paulo/noticia/2016/03/divulgacao-deaudio-de-lula-e-dilma-estimula- convulsao-social-diz-advogado.html > . Acesso em 03.01.2017.

MONTESQUIEU. Do espírito das leis. São Paulo: Saraiva, 2000.

NEVES, Marcelo. Entre Têmis e Leviatã: uma relação difícil. São Paulo: Martins Fontes, 2006

PELUSO, Antonio Cesar. http://www.conjur.com.br/2011-mai-15/stf-enfrenta-temaspolemicos-independencia-peluso-eua - 15 de maio de 2011, 17h13. Acessado em: 30/10/2016.

PORTANOVA, Rui. Motivações Ideológicas da Sentença. Porto Alegre: Livraria do Advogado, $5^{\circ}$ Ed. 2003.

TORRES, Ricardo Lobo. O orçamento na Constituição. Rio de Janeiro: Renovar, 1995.

SARLET, Ingo Wolfgang. A eficácia dos direitos fundamentais. 4. ed. Porto Alegre: Livraria do Advogado, 2015.

STRECK, Lenio Luiz. Verdade e Consenso- Constituição, hermenêutica e Teorias Discursivas. São Paulo: Saraiva, 5 Ed. 2014. 